\title{
OPEN Identification of the most suitable reference gene for gene expression studies with development and abiotic stress response in Bromus sterilis
}

\author{
Madhab Kumar Sen ${ }^{1}$, Kateřina Hamouzová ${ }^{1}$, Pavlina Košnarová ${ }^{1}$, Amit Roy ${ }^{2,3}$ \& \\ Josef Soukup ${ }^{1,3 \otimes}$
}

Bromus sterilis is an annual weedy grass, causing high yield losses in winter cereals. Frequent use of herbicides had led to the evolution of herbicide resistance in this species. Mechanisms underlying herbicide resistance in $B$. sterilis must be uncovered because this problem is becoming a global threat. qRT-PCR and the next-generation sequencing technologies can elucidate the resistance mechanisms. Although qRT-PCR can calculate precise fold changes, its preciseness depends on the expression of reference genes. Regardless of stable expression in any given condition, no gene can act as a universal reference gene. Hence, it is necessary to identify the suitable reference gene for each species. To our knowledge, there are no reports on the suitable reference gene in any brome species so far. Thus, in this paper, the stability of eight genes was evaluated using qRT-PCR experiments followed by expression stability ranking via five most commonly used software for reference gene selection. Our findings suggest using a combination of 185 rRNA and ACCase to normalise the qRT-PCR data in $B$. sterilis. Besides, reference genes are also recommended for different experimental conditions. The present study outcomes will facilitate future molecular work in $B$. sterilis and other related grass species.

One of the major plant protection problems encountered by farmers across the globe is regarding weeds. Herbicides have been widely used to manage weeds and magnify the main crop's yield quality and quantity. Despite their success in managing weeds, constant use of similar herbicides has evolved resistance in many weedy species. Owing to its rapid population dynamics and lack of efficient herbicides, barren brome (Bromus sterilis L.) has grown into a troublesome weed in winter cereals in many south and north American countries, middle and west Europe ${ }^{1-3}$. Besides the most frequent acetolactate synthase (ALS) and acetyl-CoA carboxylase (ACCase) resistance in Europe (http://www.weedscience.org/Home.aspx), United Kingdom also reported B. sterilis resistance against glyphosate in $2019^{4}$. These results indicate the prerequisite for monitoring more barren brome populations. Gene expression studies have contributed immensely in elucidating the target gene amplification and expression and the over-expression of detoxifying enzyme genes related to herbicide resistance and other abiotic stresses ${ }^{5,6}$. Moreover, with the development of next-generation sequencing technologies, there is a need to validate the expression of a greater number of genes involved in abiotic stresses ${ }^{7,8}$. qRT-PCR is widely used for such comparative gene expression studies. However, the reliability of the qRT-PCR depends on the selection of a stable reference gene.

Compared to the traditional polymerase chain reaction (PCR), quantitative real-time polymerase chain reaction (qRT-PCR) has many advantages like high specificity, rapidity and sensitivity, making it an essential part of comparative expression studies ${ }^{9,10}$. Previously, the relative quantification of gene expression was done either by Northern blot or by reverse transcription-polymerase chain reaction (RT-PCR). The most important limitation

\footnotetext{
${ }^{1}$ Department of Agroecology and Crop Production, Faculty of Agrobiology, Food and Natural Resources, Czech University of Life Sciences Prague, Kamýcká 1176, 16500 Prague 6, Suchdol, Czech Republic. ${ }^{2}$ Faculty of Forestry and Wood Sciences, EXTEMIT-K and EVA.4.0 Unit, Czech University of Life Sciences, Kamýcká 1176, 16500 Prague 6, Suchdol, Czech Republic. ${ }^{3}$ These authors contributed equally: Amit Roy and Josef Soukup. ${ }^{\square}$ email: soukup@ af.czu.cz
} 
of these methods is their inability to detect extremely low expression, resulting in replacing the pre-existing methods with microarrays and qRT-PCR ${ }^{9,11}$. Even though these modern techniques are highly sensitive and can calculate precise fold changes, their preciseness is highly dependent on the expression of a reference gene. Ideally, a reference gene refers to constitutive genes required to maintain the basic cellular functions of an organism. These genes are known to have stable gene expression in all cells under both normal and pathophysiological conditions ${ }^{12-14}$. However, the steps of qRT-PCR are reclined to variations; therefore, to overcome these variations, target gene transcription levels must be normalised to reference genes transcription levels. Any error in selecting a suitable reference gene may lead to misleading results. Hence, selecting a reliable reference gene is necessary for molecular biology-oriented studies ${ }^{9,14-17}$. The most commonly used references genes for normalisation of plant gene expression studies are ubiquitin (UBQ), $\beta$-tubulin $(\beta-T U B)$, ribosomal RNA genes (18S rRNA and $25 S$ rRNA), glyceraldehyde-3-phosphate dehydrogenase (GAPDH), eukaryotic elongation factor (eEF), eukaryotic translation initiation factor 1 (eIF1), actin (ACT), acetyl-CoA carboxylase (ACCase) etc ${ }^{9,18}$. Although these genes are known to have a stable expression in any given condition, several studies documented variability in their expression level between species of plants or different stress conditions or developmental stages ${ }^{19-21}$. As no gene can act as a universal reference, it is necessary to systematically select and identify the suitable reference gene for each species ${ }^{22,23}$.

There are no reports of a suitable reference gene in B. sterilis or any other brome species. Our study aims to identify a suitable reference gene for gene expression studies in B. sterilis (or barren brome). Increasing the number of treatments might lead to more variations in results, which decreases the chance of identifying a suitable reference gene ${ }^{9}$. In this study, we had selected eight common candidate reference genes (UBQ, ACT, GAPDH, $18 S$ rRNA, $25 S$ rRNA, ACCase, $\beta$-TUB and $e E F$ ) identified in $B$. sterilis and evaluated the stability of their gene expression in three developmental stages (two-leaves, three-leaves and four-leaves), two different plant organs (shoots and leaves) and one abiotic stress (drought stress). Among the various severe issues with detrimental effects, climate change has remained a top priority. Global warming has resulted in an increase of air temperature and evapotranspiration, leading to agricultural droughts, affecting both crops and weeds.

Low soil moisture increase the competition for water and nutrients between weeds and the crop, thus making weed management complicated. Some (usually C4) weed species gain profit from this situation. Uptake and translocation of herbicides within the plant is reduced, thereby affecting the efficacy of the applied herbicides. Hence, interest for studies under drought is recently rising ${ }^{24}$, which might require expression studies with several genes of interest. Therefore, drought stress has been included in the present study, and our recommended reference genes will be helpful in future drought-related studies.

The most suitable candidate was selected based on the ranking provided by different widely used statistical software for reference gene analysis (comparative $\Delta \mathrm{Ct}$, BestKeeper, NormFinder, geNorm and RefFinder). Additionally, the most suitable reference gene was used to validate a herbicide-stress experiment. Thus, our study provides a basis for identifying the suitable reference gene for future gene expression studies in $B$. sterilis and will aid in impending studies on the molecular basis underlying the herbicide resistance in barren brome.

\section{Results}

Primer efficiency and candidate genes expression. 1.2\% agarose gel electrophoresis was used to check the integrity of the RNA. In addition, the quantity and quality of RNA were evaluated by a nanodrop spectrophotometer (Thermo Scientific ${ }^{\mathrm{Tm}}$, US). The A260/A280 values ranged from 1.90 to 2.05. These samples were further used to synthesise cDNA, which was used for the qRT-PCR experiments. In all the qRT-PCR amplification, a single peak was obtained (supplementary Fig. 1). The selected primers for this study showed a single band in the 1.5\% agarose gel (supplementary Fig. 2) and had efficiency values ranged between 92.32 and $106.79 \%$, which falls under the acceptable range. The correlation coefficient values ranged from 0.980 to 0.999 (Table 1). The expression profile of the 8 candidate genes under different experimental conditions is shown in the Fig. 1. 18s $r R N A$ showed the lowest cycle threshold value $(\mathrm{Ct})$, indicating high expression of the gene, whereas $A C T$ showed the highest $\mathrm{Ct}$ value indicating low expression.

Gene expression stability analysis. Developmental stages-related experiments. $18 S$ rRNA was identified as the stable reference gene by comparative $\Delta \mathrm{Ct}$ and RefFinder. BestKeeper software identified ACCase as the most stable reference gene (Table 2). NormFinder analysis revealed $18 S$ rRNA and eEF as the most stable genes, whereas geNorm analysis ranked $18 S$ rRNA and ACCase as the best reference gene for developmental stages-related experiments in B. sterilis (Table 2, Fig. 2). Except, comparative $\Delta \mathrm{Ct}$, all the used software identified $G A P D H$ as the least stable gene. According to the comparative $\triangle \mathrm{Ct}$ analysis, $e E F$ is the least stable gene.

Plant organs related studies. In gene expression studies with the plant organs, $18 \mathrm{~S} r R N A$ has been ranked as the most stable gene by comparative $\Delta \mathrm{Ct}$, BestKeeper and RefFinder (Table 2). NormFinder analysis identified ACCase and eEF as the most stable genes (Table 2). Based on the geNorm analysis, 18S rRNA and ACCase might be the best reference gene for plant organs-related studies in B. sterilis (Fig. 2). $\beta$-TUB was identified as the least stable gene by comparative $\Delta \mathrm{Ct}$, BestKeeper and RefFinder, whereas NormFinder and geNorm analysis identified GAPDH as the least stable gene.

Under drought stress. For studies under drought stress, comparative $\Delta \mathrm{Ct}$ and RefFinder identified $18 \mathrm{~S} r \mathrm{RA}$ as the most suitable reference gene (Table 2). BestKeeper software identified ACCase as the most stable reference gene (Table 2). NormFinder analysis revealed GAPDH and $18 S$ rRNA as the most stable genes, whereas geNorm analysis ranked $18 S$ rRNA and $\beta-T U B$ as the best reference gene (Table 2, Fig. 2). eEF was identified as the least 


\begin{tabular}{|c|c|c|c|c|c|}
\hline Gene & Sequence & $\begin{array}{l}\text { Annealing temperature } \\
\left({ }^{\circ} \mathrm{C}\right)\end{array}$ & Amplicon length (bp) & Primer efficiency (\%) & $\mathbf{R}^{2}$ value \\
\hline $\begin{array}{l}\text { Ubiquitin_forward } \\
\text { primer }\end{array}$ & $\begin{array}{l}\text { GCACAAGCACAA } \\
\text { GAAGGTGA }\end{array}$ & \multirow{4}{*}{60} & \multirow{2}{*}{120} & \multirow{2}{*}{99.46} & \multirow{2}{*}{0.997} \\
\hline $\begin{array}{l}\text { Ubiquitin_reverse } \\
\text { primer }\end{array}$ & $\begin{array}{l}\text { AGTGGTTTGCCA } \\
\text { TGAAGGTC } \\
\end{array}$ & & & & \\
\hline Actin_forward primer & $\begin{array}{l}\text { ATGCGATTCTTCGTT } \\
\text { TGGAC }\end{array}$ & & \multirow{2}{*}{172} & \multirow{2}{*}{102.34} & \multirow{2}{*}{0.980} \\
\hline Actin_reverse primer & $\begin{array}{l}\text { GATGTCTCCAGC } \\
\text { TCCTGCTC }\end{array}$ & & & & \\
\hline $\begin{array}{l}\text { GAPDH_forward } \\
\text { primer }\end{array}$ & $\begin{array}{l}\text { AGCGACATCAAG } \\
\text { CTCAAGAA }\end{array}$ & \multirow{6}{*}{58} & \multirow{2}{*}{241} & \multirow{2}{*}{92.44} & \multirow{2}{*}{0.994} \\
\hline GAPDH_reverse primer & $\begin{array}{l}\text { CGTTGACACCAA } \\
\text { CCACAAAC }\end{array}$ & & & & \\
\hline $\begin{array}{l}\text { 18S } r R N A \_ \text {forward } \\
\text { primer }\end{array}$ & $\begin{array}{l}\text { AAACGGCTACCA } \\
\text { CATCCAAG }\end{array}$ & & \multirow{2}{*}{154} & \multirow{2}{*}{92.42} & \multirow{2}{*}{0.999} \\
\hline $\begin{array}{l}\text { 18S } r R N A \_ \text {reverse } \\
\text { primer }\end{array}$ & $\begin{array}{l}\text { CCTCCAATGGATCCT } \\
\text { CGTTA }\end{array}$ & & & & \\
\hline $\begin{array}{l}\text { 25S rRNA_forward } \\
\text { primer }\end{array}$ & $\begin{array}{l}\text { CCCAGTGCTCTG } \\
\text { AATGTCAA }\end{array}$ & & \multirow{2}{*}{211} & \multirow{2}{*}{92.32} & \multirow{2}{*}{0.999} \\
\hline $\begin{array}{l}\text { 25S rRNA_reverse } \\
\text { primer }\end{array}$ & $\begin{array}{l}\text { GTCTTCTTTCCC } \\
\text { CGCTGATT } \\
\end{array}$ & & & & \\
\hline ACCase_forward primer & $\begin{array}{l}\text { GCTGCTATTGCCAGT } \\
\text { GCTTA }\end{array}$ & \multirow{6}{*}{57} & \multirow{2}{*}{171} & \multirow{2}{*}{95.77} & \multirow{2}{*}{0.989} \\
\hline ACCase_reverse primer & $\begin{array}{l}\text { AAGCTTGTTCAG } \\
\text { GGCAGAAA }\end{array}$ & & & & \\
\hline $\begin{array}{l}\beta \text {-Tubulin_forward } \\
\text { primer }\end{array}$ & $\begin{array}{l}\text { AGTACCGTGCCC } \\
\text { TCACAGTC }\end{array}$ & & \multirow{2}{*}{150} & \multirow{2}{*}{106.79} & \multirow{2}{*}{0.996} \\
\hline $\begin{array}{l}\beta \text {-Tubulin_reverse } \\
\text { primer }\end{array}$ & $\begin{array}{l}\text { TCTGCTCGTCAACCT } \\
\text { CCTTT }\end{array}$ & & & & \\
\hline $\begin{array}{l}\text { eukaryotic elongation } \\
\text { factor_forward primer }\end{array}$ & $\begin{array}{l}\text { CCTGCACTGTCATTG } \\
\text { ATGCT }\end{array}$ & & \multirow{2}{*}{185} & \multirow{2}{*}{94.51} & \multirow{2}{*}{0.988} \\
\hline $\begin{array}{l}\text { eukaryotic elongation } \\
\text { factor_reverse primer }\end{array}$ & $\begin{array}{l}\text { CTGCCTGACACC } \\
\text { AAGAGTGA }\end{array}$ & & & & \\
\hline
\end{tabular}

Table 1. Primer information of the eight candidate reference genes.

stable gene by $\triangle \mathrm{Ct}$, BestKeeper and RefFinder, whereas NormFinder and geNorm analysis identified $U B Q$ as the least stable gene for studies under drought stress on $B$. sterilis.

Combined conditions. When all the conditions were taken together, $18 S \mathrm{rRNA}$ was identified as the most stable reference gene, irrespective of the method (Table 2, Fig. 2). NormFinder analysis results for combined conditions revealed that $U B Q$ and ACCase could be considered the best reference gene, and the geNorm algorithm ranked $18 S$ rRNA and ACCase, as the best reference gene (Table 2, Fig. 2). $\beta$-TUB was identified as the least stable gene by comparative $\triangle \mathrm{Ct}$, BestKeeper and RefFinder, whereas NormFinder and geNorm analysis identified GAPDH as the least stable gene.

Pairwise variation analysis. The pairwise variation $(\mathrm{Vn} / \mathrm{Vn}+1)$ was calculated based on the geNorm algorithm. The optimal number of the reference genes required for the normalisation were determined from the pairwise variation results, based on the average expression stability $(M)$ values (cutoff: $M<1.5$ ). The optimal number of the reference genes required for the normalisation for experiments related to the developmental stages and plant organs are 1 and 2, respectively. However, to avoid any biases in the normalization, we recommend using 2 reference genes for developmental stages. Hence, we recommend using $18 S$ rRNA and ACCase, as housekeeping genes for developmental stages and plant organ-related studies in B. sterilis. Under drought stress, 4 candidate genes ( $18 \mathrm{~S} r R N A, \beta-T U B, 25 S$ rRNA and ACCase) were considered suitable for normalisation. When all the conditions were considered together, the pairwise variation result suggested that 2 reference genes will be required for the normalisation (Fig. 3). Therefore, $18 \mathrm{~S} r R N A$ and ACCase were identified as the most suitable gene when all the conditions were considered together.

Relative expression of the acetolactate synthase (ALS) gene under herbicide stress. Based on the analysis of the commonly used software for reference gene analysis, $18 S$ rRNA and a combination of $18 S$ rRNA and ACCase were identified as the most suitable candidate genes for gene expression studies in Bromus sterilis, whereas $\beta$-TUB as the most unstable gene. To validate the reliability of the candidate genes, relative expression of the acetolactate synthase under herbicide stress was evaluated using the best and the least stable candidate genes. When normalised with $18 S$ rRNA and a combination of $18 \mathrm{~S}$ rRNA and ACCase, B. sterilis biotype showed twofold $A L S$ gene overexpression after herbicide treatment compared to the control, whereas with $\beta-T U B$, the result is almost eight times (Fig. 4). 


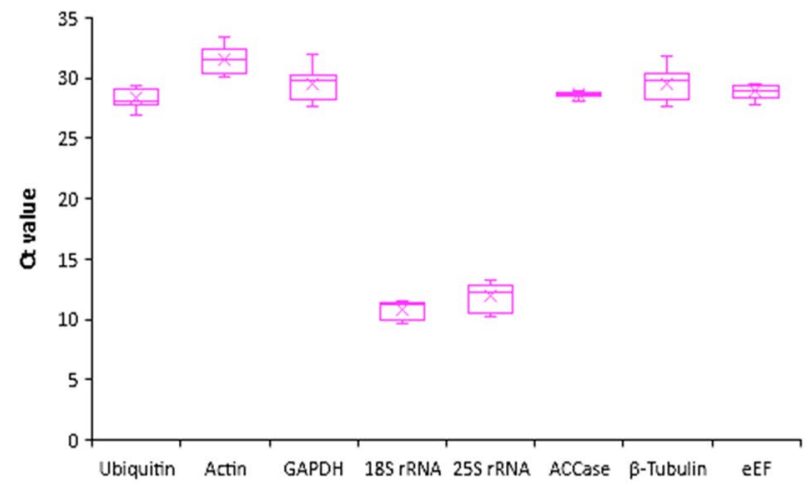

A. Developmental stages

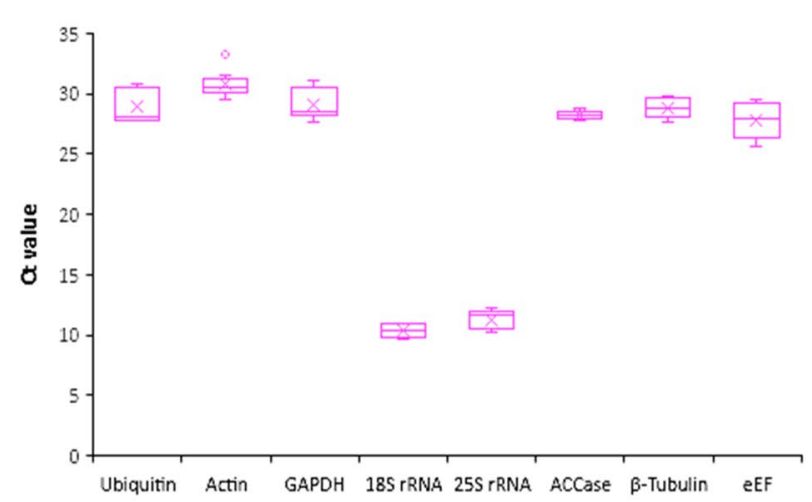

C. Drought stress

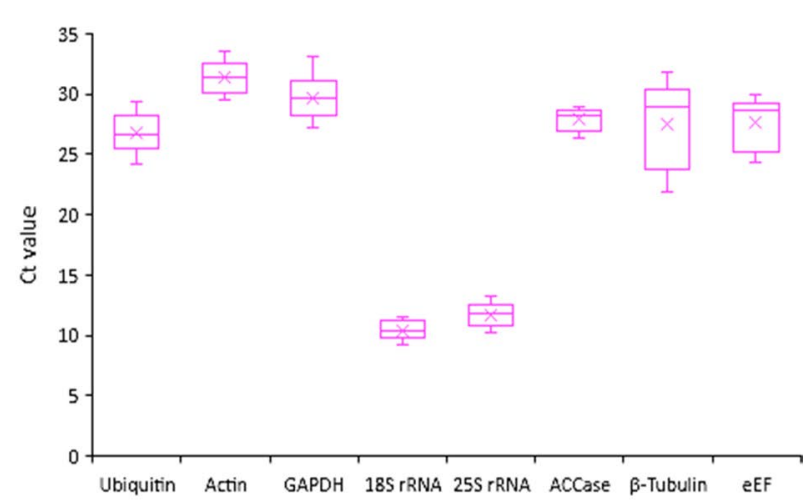

B. Plant organs

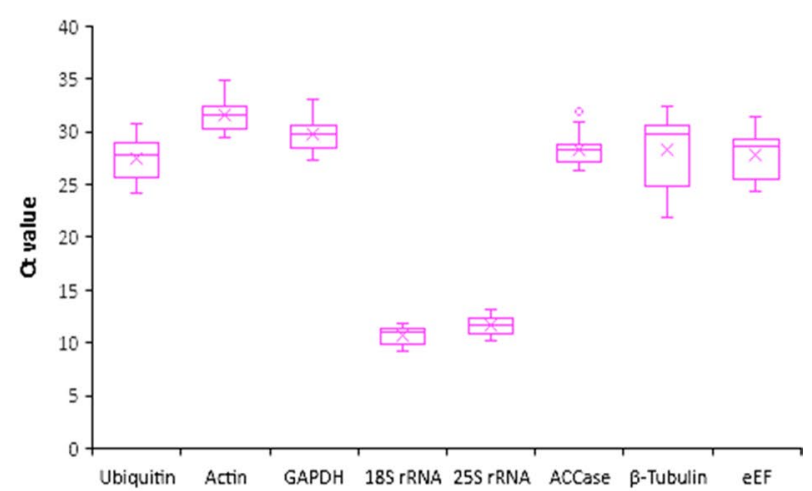

D. All combined

Figure 1. Expression levels of the eight candidate genes. Ct values obtained from three developmental stages (2nd, 3rd and 4th leaves), two different plant organs (shoots and leaves) and abiotic stress (drought stress) were compared and plotted.

\section{Discussion}

Recent reports from the United Kingdom and the Czech Republic on B. sterilis, developing resistance against commonly used herbicides, indicate that if they remained uncontrolled, these species might become a concern worldwide ${ }^{25,26}$. Herbicide resistance mechanisms can be target-site based (TSR) and/or non-target site-based (NTSR). Target-site based mechanisms involve nucleotide polymorphisms $s^{27}$, gene amplification ${ }^{6}$ and gene overexpression $^{28}$, whereas increased detoxification by enhanced metabolism ${ }^{29,30}$ and/or reduced herbicide uptake and translocation ${ }^{29}$ fall under non-target site-based herbicide resistance. Irrespective of the mechanism/s of resistance, qRT-PCR and the next-generation sequencing technologies have been used recently as a common technique to investigate the resistance mechanism in different weed species ${ }^{5}$. qRT-PCR experiments require an appropriate reference gene to normalise the target transcript levels. Any misapprehension in selecting a stable reference gene might lead to ambiguous results. Hence, the selection of a reliable reference gene is obligatory. Even though suitable candidate genes under different experimental condition were identified in many weedy species, like Alopecurus sp. ${ }^{20}$, Eleusine sp. ${ }^{8}$, Avena sp. ${ }^{31,32,33}$, Descurainia sp. ${ }^{34}$ etc., but to date, there are no reports on the systematic selection of stable reference genes under any conditions for barren brome or any other related brome species.

This study used qRT-PCR to evaluate the expression stability of eight candidate reference genes in barren brome under different experimental conditions. The most stable reference genes for each experimental condition were identified exclusively. geNorm software identified the ideal pair of genes with the minor variation in their expression ratios for each experimental condition. For studies related to life stages, geNorm identified that combining two reference genes would be suitable for normalising the qRT-PCR based gene expression values. $18 \mathrm{~S}$ rRNA and ACCase was chosen as the best reference gene for the studies with life stages of $B$. sterilis. For studies related to plant organs and under drought stress, pairwise variation analysis recommended using two and four genes, respectively. $18 S \mathrm{rRNA}$ and ACCase were chosen as the most suitable candidates for plant organs-related studies, whereas, for studies under drought stress, we recommend using $18 S$ rRNA, $\beta$-TUB, $25 S$ rRNA and ACCase. When all the conditions were considered together, $18 S$ rRNA and ACCase were identified as the most suitable gene. Validation under herbicide stress indicated that both $18 S$ rRNA and the combination of $18 S$ rRNA and ACCase could be suitable. $18 S$ rRNA, a component of the $40 \mathrm{~S}$ ribosomal small subunit in eukaryotes, has been recognised to have a steady expression in grasses under different stresses in earlier studies ${ }^{35,36}$. 18S rRNA is a primary constituent of all eukaryotic cells. Hence, $18 \mathrm{~S} r R N A$ is known to have extremely high expression in most cell types, so it can be challenging to use it as an endogenous normaliser gene. Moreover, synchronized 


\begin{tabular}{|c|c|c|c|c|c|c|c|c|}
\hline \multirow[b]{2}{*}{ Rank } & \multicolumn{2}{|c|}{ Comparative $\Delta \mathrm{Ct}$} & \multicolumn{2}{|c|}{ BestKeeper } & \multicolumn{2}{|l|}{ NormFinder } & \multicolumn{2}{|l|}{ RefFinder } \\
\hline & Genes & Average of SD & Genes & Std dev $[+/-\mathrm{CP}]$ & Gene name & Stability value & Genes & Geomean of ranking values \\
\hline \multicolumn{9}{|c|}{ Life stages (two-leaves stage, three-leaves stage and four-leaves stage) } \\
\hline 1 & $18 S$ rRNA & 0.7 & ACCase & 0.19 & $18 S$ rRNA & 0.132 & $18 S$ rRNA & 1.73 \\
\hline 2 & Actin & 0.79 & eEF & 0.47 & ACCase & 0.134 & $25 S$ rRNA & 2.71 \\
\hline 3 & $25 S$ rRNA & 0.8 & $18 S$ rRNA & 0.65 & Actin & 0.154 & Actin & 2.99 \\
\hline 4 & $\beta$-tubulin & 0.81 & Ubiquitin & 0.65 & $e E F$ & 0.166 & $\beta$-tubulin & 3.25 \\
\hline 5 & ACCase & 0.89 & Actin & 0.86 & $\beta$-tubulin & 0.215 & ACCase & 3.64 \\
\hline 6 & GAPDH & 0.94 & $25 S$ rRNA & 0.88 & $25 S$ rRNA & 0.224 & Ubiquitin & 5.63 \\
\hline 7 & Ubiquitin & 0.94 & $\beta$-tubulin & 0.97 & Ubiquitin & 0.248 & $e E F$ & 5.66 \\
\hline 8 & $e E F$ & 1.18 & GAPDH & 0.99 & GAPDH & 0.275 & GAPDH & 6.4 \\
\hline $\begin{array}{l}\text { Best combination of two } \\
\text { genes }\end{array}$ & & & & & $18 S r R N A$ and $e E F$ & 0.102 & & \\
\hline \multicolumn{9}{|c|}{ Plant organs (stem and leaf) } \\
\hline 1 & $18 S$ rRNA & 1.39 & $18 S$ rRNA & 0.76 & $18 S$ rRNA & 0.125 & $18 S$ rRNA & 1 \\
\hline 2 & $25 S$ rRNA & 1.48 & ACCase & 0.83 & ACCase & 0.146 & $25 S$ rRNA & 1.86 \\
\hline 3 & Actin & 1.67 & $25 S$ rRNA & 0.89 & $\beta$-tubulin & 0.204 & Actin & 3.46 \\
\hline 4 & Ubiquitin & 1.72 & Actin & 1.1 & Ubiquitin & 0.206 & ACCase & 3.76 \\
\hline 5 & ACCase & 1.79 & GAPDH & 1.38 & $25 S$ rRNA & 0.214 & Ubiquitin & 4.36 \\
\hline 6 & GAPDH & 2.02 & Ubiquitin & 1.51 & Actin & 0.214 & GAPDH & 5.73 \\
\hline 7 & $e E F$ & 2.37 & $e E F$ & 1.81 & $e E F$ & 0.229 & $e E F$ & 7 \\
\hline 8 & $\beta$-tubulin & 2.89 & $\beta$-tubulin & 3.01 & GAPDH & 0.323 & $\beta$-tubulin & 8 \\
\hline $\begin{array}{l}\text { Best combination of two } \\
\text { genes }\end{array}$ & & & & & ACCase and $e E F$ & 0.113 & & \\
\hline \multicolumn{9}{|c|}{ Drought stress (water-treated vs untreated) } \\
\hline 1 & $18 S$ rRNA & 0.93 & ACCase & 0.26 & $e E F$ & 0.191 & $18 S$ rRNA & 1.19 \\
\hline 2 & $\beta$-tubulin & 1 & $18 S$ rRNA & 0.54 & $\beta$-tubulin & 0.295 & $\beta$-tubulin & 2 \\
\hline 3 & $25 S$ rRNA & 1.05 & $25 S$ rRNA & 0.73 & $18 S$ rRNA & 0.304 & $25 S$ rRNA & 3 \\
\hline 4 & ACCase & 1.21 & $\beta$-tubulin & 0.75 & ACCase & 0.326 & ACCase & 3.25 \\
\hline 5 & Actin & 1.24 & Actin & 0.77 & GAPDH & 0.349 & Actin & 5 \\
\hline 6 & GAPDH & 1.27 & GAPDH & 1.02 & $25 S$ rRNA & 0.406 & GAPDH & 5.42 \\
\hline 7 & Ubiquitin & 1.35 & Ubiquitin & 1.17 & Actin & 0.516 & Ubiquitin & 6.74 \\
\hline 8 & $e E F$ & 2.3 & $e E F$ & 1.48 & Ubiquitin & 0.581 & $e E F$ & 8 \\
\hline $\begin{array}{l}\text { Best combination of two } \\
\text { genes }\end{array}$ & & & & & GAPDH and $18 S$ rRNA & 0.165 & & \\
\hline \multicolumn{9}{|c|}{ All samples (plant life stages, plant organs and drought stress) } \\
\hline 1 & $18 S$ rRNA & 1.39 & 18S rRNA & 0.72 & $18 S$ rRNA & 0.175 & $18 S$ rRNA & 1 \\
\hline 2 & $25 S$ rRNA & 1.48 & ACCase & 0.73 & ACCase & 0.198 & $25 S r R N A$ & 1.86 \\
\hline 3 & Actin & 1.69 & $25 S$ rRNA & 0.8 & B-Tubulin & 0.237 & Actin & 3.22 \\
\hline 4 & ACCase & 1.75 & Actin & 1.06 & $e E F$ & 0.249 & ACCase & 3.36 \\
\hline 5 & Ubiquitin & 1.97 & GAPDH & 1.33 & $25 S$ rRNA & 0.257 & Ubiquitin & 5.48 \\
\hline 6 & GAPDH & 1.97 & Ubiquitin & 1.68 & Actin & 0.303 & GAPDH & 5.48 \\
\hline 7 & $e E F$ & 2.39 & $e E F$ & 1.77 & Ubiquitin & 0.323 & $e E F$ & 7 \\
\hline 8 & $\beta$-tubulin & 2.78 & $\beta$-tubulin & 2.75 & GAPDH & 0.369 & $\beta$-tubulin & 8 \\
\hline $\begin{array}{l}\text { Best combination of two } \\
\text { genes }\end{array}$ & & & & & Ubiquitin and ACCase & 0.142 & & \\
\hline
\end{tabular}

Table 2. Expression stability of candidate genes analysed by $\Delta \mathrm{Ct}$, BestKeeper, NormFinder and RefFinder. RefFinder compares the results evaluated by four different programs (comparative $\Delta \mathrm{Ct}$ method, geNorm, BestKeeper and NormFinder) and based on the geomean of ranking values, provides a comprehensive ranking. St. dev.: standard deviation; St. dev [+/-CP]: standard deviation of crossing point (CP) values, eEF: eukaryotic elongation factor, ACCase: Acetyl-CoA carboxylase.

use of multiple reference genes will also decrease the chance of biased normalisations. Finally, from our study results, $18 S$ rRNA and ACCase appeared to be the most suitable reference genes to normalise the qRT-PCR data in B. sterilis.

Rapid advances in molecular biology techniques in plant biotechnology have increased the demand for identification of reference genes, which will be more stable than the traditional reference genes. The reference genes identified and validated in our study will assist the studies related to the elucidation of abiotic stress and its regulatory mechanisms. Comparative RNA-seq transcriptome analysis between the control and experimental plants 

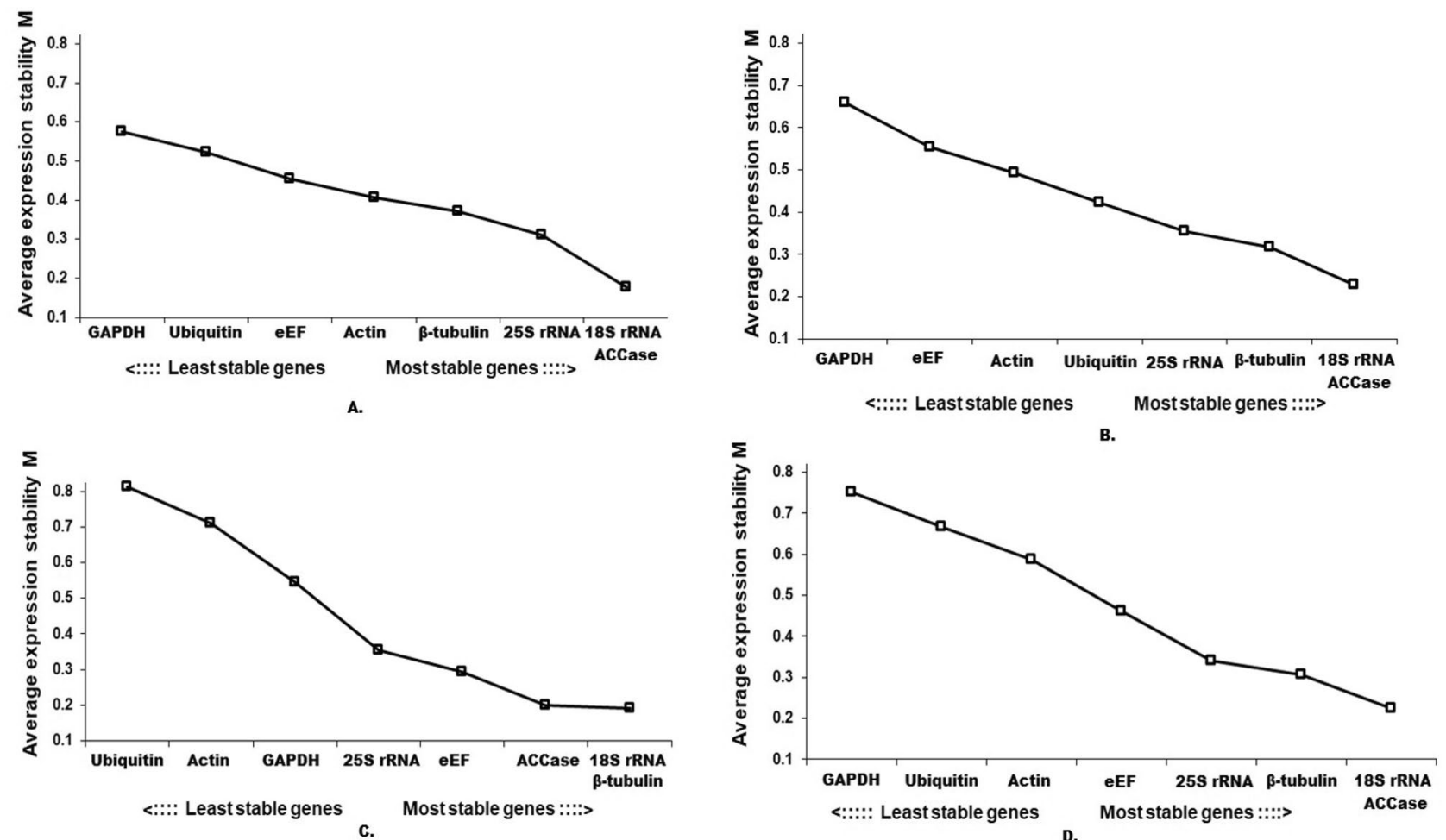

Figure 2. geNorm ranking of the candidate genes under different tested conditions. (A) Developmental stages, (B) plant organs, (C) Drought stress, and (D) All combined.

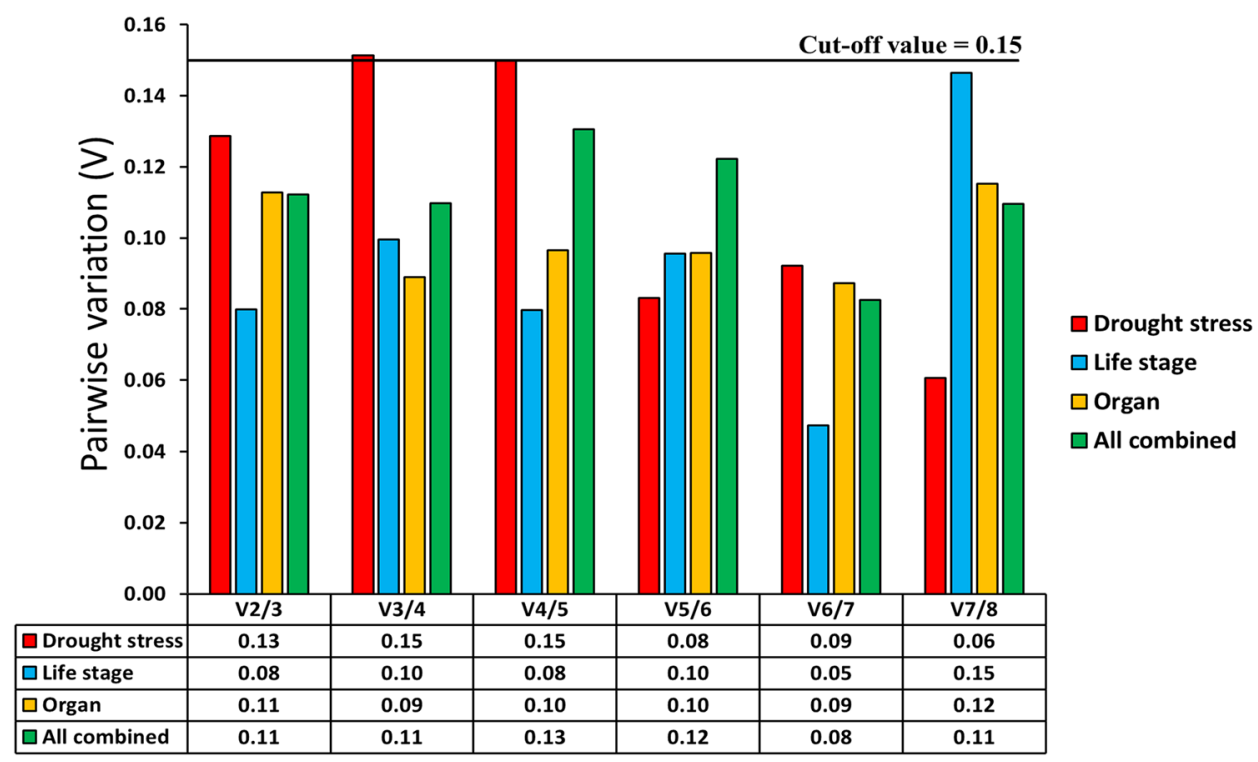

Figure 3. Pairwise variation to determine the optimal number of reference genes. The recommended cutoff value under which there is no need for another gene is 0.15 .

can be regarded as the most straightforward way to identify the genes involved in abiotic stresses like herbicide stress $^{20}$. Recent studies on herbicide resistance mechanisms of B. sterilis suggest that both TSR and NTSR can be linked with the herbicide resistance in these species ${ }^{25,26}$. Nevertheless, detailed follow-up studies are essential to delineate further the regulatory mechanisms underlying the observed herbicide resistance mechanism ${ }^{24}$. However, among the herbicide resistance mechanisms, NTSR mechanisms are considered more complex to elucidate than the TSRs ${ }^{20}$. Comparative RNA-seq studies between the herbicide-resistant and susceptible plants will facilitate unravelling plausible resistance mechanisms in barren brome. Nevertheless, the RNA-seq data 


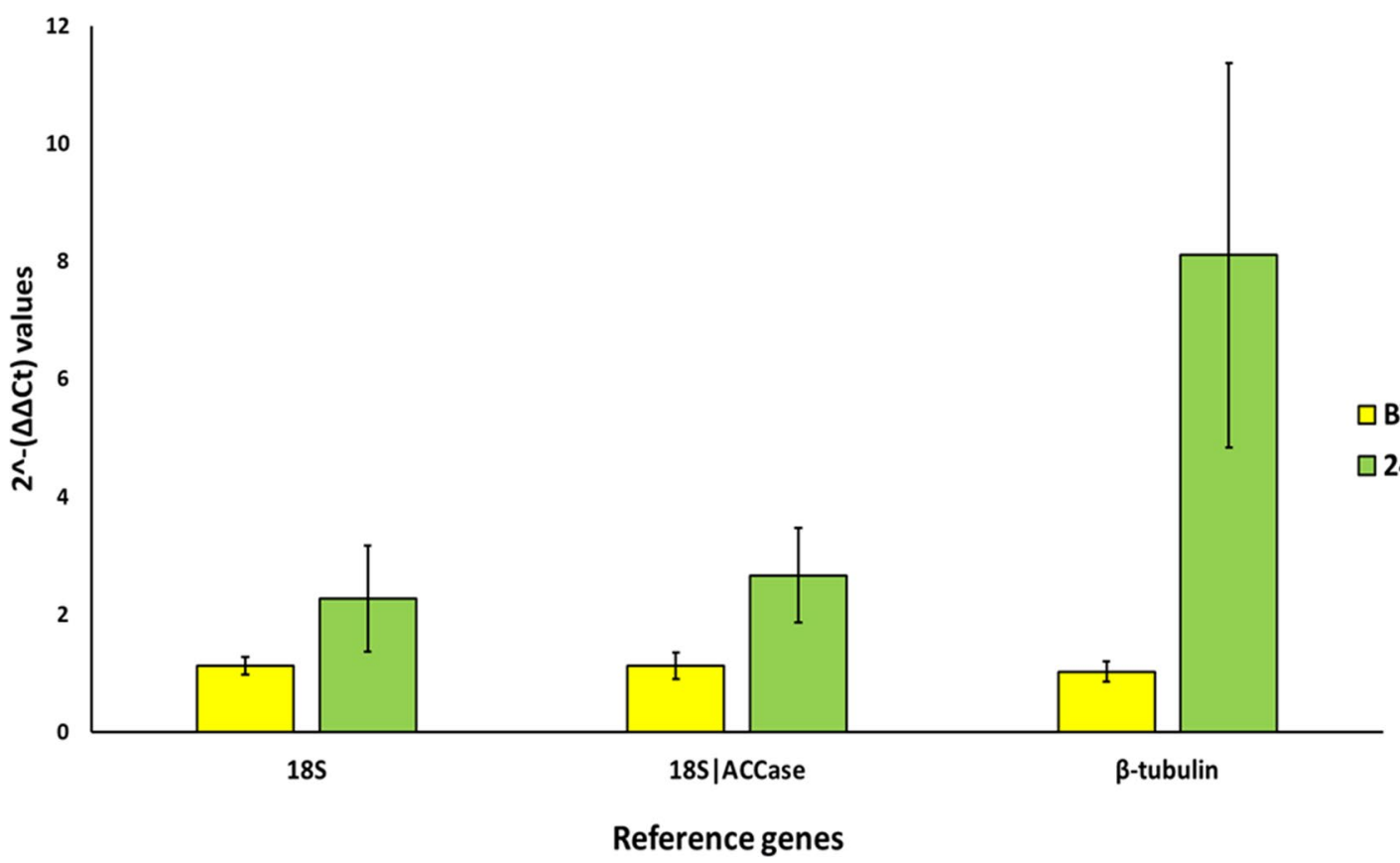

Figure 4. Relative expression of the acetolactate synthase gene under herbicide stress. Relative gene expression before herbicide treatment (BT) and $24 \mathrm{~h}$ after treatment (24 HAT) were compared, and normalization was done with $18 S$ rRNA, $18 S$ rRNA|ACCase and $\beta$-tubulin.

should be further cross-checked via qPCR, whose reliability depends on selecting the reference genes. This is the first study to evaluate and validate experiment-condition specific reference genes in brome species to the best of our knowledge. We had identified and validated internal reference gene suitable for normalising qRT-PCR experiments. Thus, our reference genes can be used during any RNA-seq based transcriptome or gene expression studies on B. sterilis. Our findings provide a basis for future molecular work on B. sterilis and can also be used during gene expression studies in other related species after preliminary validation.

\section{Methods}

Plant materials. A single population of B. sterilis, used for this study. B. sterilis was collected from winter wheat fields in the Ústecký region of the Czech Republic (50.2612525 N, 13.4818572 E). Bromus sterilis is an undesirable arable weed, so there are no specific country regulations for manipulation with it. No permissions were necessary to collect plant samples. $25 \mathrm{~cm}^{2}$ pots (filled with chernozem soil, clay content $46 \%$ (loamy soil), soil pH (KCl) 7.5, sorption capacity of soil: $209 \mathrm{mmol}(+), 87 \mathrm{mg} \mathrm{kg}^{-1} \mathrm{P}, 203 \mathrm{mg} \mathrm{kg}^{-1} \mathrm{~K}, 197 \mathrm{mg} \mathrm{kg}^{-1} \mathrm{Mg}$, $8073 \mathrm{mg} \mathrm{kg}^{-1} \mathrm{Ca}$ ), were used to plant the seeds. The pots were kept in an open-air vegetation hall (with rooftop). Plant samples from three developmental stages (2-leaves stage, 3-leaves stage and 4-leaves stage), two different plant organs (shoots and leaves) and one abiotic stress (drought stress) were used for this study. For drought stress, watering was interrupted when the plants reach the three to four leaves stage, till symptoms of wilting were observed. Wilted leaves samples were collected and stored at $-80^{\circ} \mathrm{C}$ (until further use). For herbicide stress, the plants were treated with pyroxsulam (a group of triazolopyrimidine sulfonamide ALS-inhibiting herbicide) at two to three leaf stage with recommended dose $\left(1.875 \mathrm{~g}\right.$ a.i. ha $\left.{ }^{-1}\right)$. Herbicide was sprayed using a laboratory spray chamber equipped with a Lurmark $015 \mathrm{~F} 80$ nozzle with a spray volume of $250 \mathrm{~L} \mathrm{ha}^{-1}$ and pressure $120 \mathrm{kPa}$. The leaves samples were collected before treatment and $24 \mathrm{~h}$ after treatment and stored at $-80^{\circ} \mathrm{C}$ for RNA extraction. All experiments conducted in this study, including the collection of plant material, are in compliance with relevant institutional, national, and international guidelines and legislation.

RNA extraction, complementary DNA (CDNA) synthesis and primer design. RNeasy Mini Kit (Qiagen, Hilden, Germany) was used to extract RNA from the fresh tissues ( $\pm 80 \mathrm{mg}$ per sample). TURBO DNA-free (Invitrogen, US) Kit was used to remove gDNA contamination. RNA integrity was verified by running the samples on $1.2 \%$ agarose gel electrophoresis. cDNA was synthesised by High Capacity cDNA Reverse Transcription Kit (Applied Biosystems, USA) from the quality-checked gDNA-free RNA template $(1 \mu \mathrm{g}$ per reaction). Degenerate primers were designed for eight common candidate reference genes (UBQ, ACT, GAPDH, $18 S$ rRNA, $25 S$ rRNA, ACCase, $\beta$-TUB and $e E F$ ) based on their homologous sequences in other plants species (Table 1). The primers were designed using Primer-BLAST (https://www.ncbi.nlm.nih.gov/tools/primer-blast/) and Primer3 software (https://bioinfo.ut.ee/primer3-0.4.0/). All the primers were tested by general PCR, performed using a C1000 thermocycler (Bio-Rad, Hercules, CA, USA), using cDNA template (10 ng per reaction). The thermocycler was programmed at an initial denaturation step at $95^{\circ} \mathrm{C}$ for $5 \mathrm{~min}$, followed by 40 cycles of $5 \mathrm{~s}$ at $95^{\circ} \mathrm{C}, 10 \mathrm{~s}$ at 57 to $60^{\circ} \mathrm{C}$ (based on the annealing temperature of the primer pairs), and $30 \mathrm{~s}$ at $72{ }^{\circ} \mathrm{C}$ along 
with a final extension step for $10 \mathrm{~min}$ at $72{ }^{\circ} \mathrm{C}$. The PCR amplified products were verified in the $1.5 \%$ agarose gel electrophoresis (data not shown).

qRT-PCR experiment and data analysis. PowerUp SYBR Green Master Mix (Applied Biosystems, USA) was used to conduct qRT-PCR assay in StepOne ${ }^{\text {tw }}$ Real-Time PCR System (Applied Biosystems, USA). The

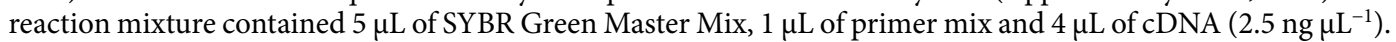
For primer efficiency $(\mathrm{E})$ and correlation coefficient $\left(\mathrm{R}^{2}\right)$ calculation, $\mathrm{qRT}$-PCR assay was performed with diluted series of cDNA samples. $E=\left\{10^{(-1 / \text { slope })}-1^{\star} 100 \%\right\}$ was used to calculate the values of $\mathrm{E}$. The thermocycler was programmed at an initial denaturation step at $95^{\circ} \mathrm{C}$ for $10 \mathrm{~min}$, followed by 40 cycles of $15 \mathrm{~s}$ at $95{ }^{\circ} \mathrm{C}$ and $1 \mathrm{~min}$ at 57 to $60^{\circ} \mathrm{C}$ (based on the annealing temperature of the primer pairs). To obtain the melting curves, stepwise heating was performed from 60 to $95^{\circ} \mathrm{C}$. All qRT-PCR experiments were conducted with 5 biological replicates. Quantification cycle threshold (Ct) values obtained from the StepOne Real-Time PCR System (Applied Biosystems, USA) was exported and used for further calculations. Gene expression stabilities of the eight candidate genes in the B. sterilis were examined by geNorm, NormFinder and BestKeeper, according to Chen et al. ${ }^{8}$. Besides, comparative $\Delta \mathrm{Ct}^{37}$ and RefFinder ${ }^{8}$ were also used. Before and after herbicide treatment, the relative ALS gene expression was calculated using the $2^{-\Delta \Delta \mathrm{Ct}} \operatorname{method}^{38,39}$. NormFinder software estimates the intra- and intergroup variation. These variations are then combined into a stability value. The gene with minimal variation is ranked as the best by the software. geNorm program estimates an expression stability value $(\mathrm{M})$ for each gene. Genes with the lowest $M$ values have the most stable expression. BestKeeper ranks the candidate genes based on standard deviation values of cycle threshold (Ct) or crossing point values (CP) and coefficient of correlation (r) values. A gene with a standard deviation value below 1 and a coefficient of correlation value close to 1 is considered to have more stable gene expression than others. RefFinder integrates the available well-known programs for reference gene screening (geNorm, NormFinder, BestKeeper, and the comparative Delta-Ct method) and calculates the geometric mean of ranking values to give the overall ranking. The genes with a minimal geometric mean of ranking values are categorized as the best ${ }^{37}$.

Ethical approval. No permissions were necessary to collect plant samples. All experiments conducted in this study, including the collection of plant material, are in compliance with relevant institutional, national, and international guidelines and legislation.

Ethics statement. This article does not contain any studies with human or animal subjects.

Received: 27 January 2021; Accepted: 11 June 2021

Published online: 28 June 2021

\section{References}

1. Žd'árková, V., Hamouzová, K., Holec, J., Janků, J. \& Soukup, J. Seed ecology of Bromus sterilis L. Julius-Kühn-Arch. 443, 156-164 (2014).

2. Jursík, M., Kolářová, M., Soukup, J. \& Ždárková, V. Effects of adjuvants and carriers on propoxycarbazone and pyroxsulam efficacy on Bromus sterilis in winter wheat. Plant Soil Environ. 62, 447-452 (2016).

3. Ždárková, V., Hamouzová, K., Kolářová, M. \& Soukup, J. Germination responses to water potential in Bromus sterilis L. under different temperatures and light regimes. Plant Soil Environ. 63, 368-374 (2017).

4. Davies, L. R., Hull, R., Moss, S. \& Neve, P. The first cases of evolving glyphosate resistance in UK poverty brome (Bromus sterilis) populations. Weed Sci. 67, 41-47 (2019).

5. Gaines, T. A. et al. Gene amplification confers glyphosate resistance in Amaranthus palmeri. PNAS 107, 1029-1034 (2010).

6. Salas, R. A., Scott, R. C., Dayan, F. E. \& Burgos, N. R. EPSPS gene amplification in glyphosate-resistant Italian ryegrass (Lolium perenne ssp. multiflorum) populations from arkansas (United States). J. Agric. Food Chem. 63, 5885-5893 (2015).

7. Gaines, T. A. et al. RNA-Seq transcriptome analysis to identify genes involved in metabolism-based diclofop resistance in Lolium rigidum. Plant J. 78, 865-876 (2014).

8. Chen, J. et al. Selection of relatively exact reference genes for gene expression studies in goosegrass (Eleusine indica) under herbicide stress. Sci. Rep. 7, 46494 (2017).

9. Joseph, J. T., Poolakkalody, N. J. \& Shah, J. M. Plant reference genes for development and stress response studies. J. Biosci. 43, 173-187 (2018).

10. Nolan, T., Hands, R. E. \& Bustin, S. A. Quantification of mRNA using real-time RT-PCR. Nat. Protoc. 1, 1559-1582 (2006).

11. Ginzinger, D. G. Gene quantification using real-time quantitative PCR: An emerging technology hits the mainstream. Exp. Hematol. 30, 503-512 (2002).

12. Huggett, J., Dheda, K., Bustin, S. \& Zumla, A. Real-time RT-PCR normalisation; strategies and considerations. Genes Immun. 6, 279-284 (2005).

13. Guénin, S. et al. Normalisation of qRT-PCR data: The necessity of adopting a systematic, experimental conditions-specific, validation of references. J. Exp. Bot. 60, 487-493 (2009).

14. Bustin, S. Quantification of mRNA using real-time reverse transcription PCR (RT-PCR): Trends and problems. J. Mol. Endocrinol. 29, 23-39 (2002)

15. Rocha, A. J., Monteiro-Júnior, J. E., Freire, J. E. C., Sousa, A. J. S. \& Fonteles, C. S. R. Real time PCR: The use of reference genes and essential rules required to obtain normalisation data reliable to quantitative gene expression. J. Mol. Biol. Res. 5, 45 (2015).

16. Chapman, J. R. \& Waldenström, J. With reference to reference genes: A systematic review of endogenous controls in gene expression studies. PLoS ONE 10, e0141853 (2015).

17. Nestorov, J., Matić, G., Elaković, I. \& Tanić, N. Gene expression studies: How to obtain accurate and reliable data by quantitative real-time RT PCR/izučavanje ekspresije gena: kako dobiti tačne i pouzdane podatke kvantitativnim rt pcr-om u realnom vremenu. J. Med. Biochem. 32, 325-338 (2013).

18. Kozera, B. \& Rapacz, M. Reference genes in real-time PCR. J. Appl. Genet. 54, 391-406 (2013). 
19. Czechowski, T., Stitt, M., Altmann, T., Udvardi, M. K. \& Scheible, W.-R. Genome-wide identification and testing of superior reference genes for transcript normalization in arabidopsis. Plant Physiol. 139, 5-17 (2005).

20. $\mathrm{Xu}, \mathrm{H}$. et al. Identification of reference genes for studying herbicide resistance mechanisms in Japanese foxtail (Alopecurus japonicus). Weed Sci. 65, 557-566 (2017).

21. Hong, S.-Y., Seo, P. J., Yang, M.-S., Xiang, F. \& Park, C.-M. Exploring valid reference genes for gene expression studies in Brachypodium distachyon by real-time PCR. BMC Plant Biol. 8, 112 (2008).

22. Gutierrez, L. et al. The lack of a systematic validation of reference genes: A serious pitfall undervalued in reverse transcriptionpolymerase chain reaction (RT-PCR) analysis in plants. Plant Biotechnol. J. 6, 609-618 (2008).

23. Tong, Z., Gao, Z., Wang, F., Zhou, J. \& Zhang, Z. Selection of reliable reference genes for gene expression studies in peach using real-time PCR. BMC Mol. Biol. 10, 71 (2009).

24. Ramesh, K., Matloob, A., Aslam, F., Florentine, S. K. \& Chauhan, B. S. Weeds in a changing climate: Vulnerabilities, consequences, and implications for future weed management. Front. Plant Sci. 8, 95 (2017).

25. Sen, M. K. et al. Enhanced metabolism and target gene overexpression confer resistance against acetolactate synthase-inhibiting herbicides in Bromus sterilis. Pest Manag. Sci. 77(4), 2122-2128 (2021).

26. Davies, L. R., Onkokesung, N., Brazier-Hicks, M., Edwards, R. \& Moss, S. Detection and characterisation of resistance to acetolactate synthase inhibiting herbicides in Anisantha and Bromus species in the United Kingdom. Pest Manag. Sci. 76, 2473-2482 (2020).

27. Anthimidou, E., Ntoanidou, S., Madesis, P. \& Eleftherohorinos, I. Mechanisms of Lolium rigidum multiple resistance to ALS- and ACCase-inhibiting herbicides and their impact on plant fitness. Pestic. Biochem. Physiol. 164, 65-72 (2020).

28. Gaines, T. A. et al. Mechanisms of evolved herbicide resistance. J. Biol. Chem. 295, 10307-10330 (2020).

29. Pan, L., Gao, H., Xia, W., Zhang, T. \& Dong, L. Establishing a herbicide-metabolising enzyme library in Beckmannia syzigachne to identify genes associated with metabolic resistance. J. Exp. Bot. 67, 1745-1757 (2016).

30. Jugulam, M. \& Shyam, C. Non-target-site resistance to herbicides: Recent developments. Plants 8, 417 (2019).

31. Akbarabadi, A., Ismaili, A., Kahrizi, D. \& Firouzabadi, F. N. Validation of expression stability of reference genes in response to herbicide stress in wild oat (Avena ludoviciana). Cell Mol. Biol. (Noisy-le-grand) 64, 113-118 (2018).

32. Ruduś, I. \& Kępczyński, J. Reference gene selection for molecular studies of dormancy in wild oat (Avena fatua L.) caryopses by RT-qPCR method. PLoS ONE 13, e0192343 (2018).

33. Wrzesińska, B., Kierzek, R. \& Obrępalska-Stęplowska, A. Evaluation of six commonly used reference genes for gene expression studies in herbicide-resistant Avena fatua biotypes. Weed Res. 56, 284-292 (2016).

34. Xu, X. et al. Selection of relatively exact reference genes for gene expression studies in flixweed (Descurainia sophia) by quantitative real-time polymerase chain reaction. Pestic. Biochem. Physiol. 127, 59-66 (2016).

35. Jain, M., Nijhawan, A., Tyagi, A. K. \& Khurana, J. P. Validation of housekeeping genes as internal control for studying gene expression in rice by quantitative real-time PCR. Biochem. Biophys. Res. Commun. 345, 646-651 (2006).

36. Petit, C., Pernin, F., Heydel, J.-M. \& Délye, C. Validation of a set of reference genes to study response to herbicide stress in grasses. BMC Res. Notes 5, 18 (2012).

37. Liu, J. et al. Selection and evaluation of potential reference genes for gene expression analysis in Avena fatua Linn. Plant Protect. Sci. 55, 61-71 (2018).

38. Roy, A. \& Palli, S. R. Epigenetic modifications acetylation and deacetylation play important roles in juvenile hormone action. BMC Genomics 19, 934 (2018).

39. Livak, K. J. \& Schmittgen, T. D. Analysis of relative gene expression data using real-time quantitative PCR and the $2-\Delta \Delta C T$ method. Methods 25, 402-408 (2001).

\section{Acknowledgements}

The authors acknowledge Dr. Todd Gaines (Colorado State University, Fort Collins, CO, USA), Mr. Ram Kumar (Department of Crop Protection, Faculty of Agrobiology, Food and Natural Resources, Czech University of Life Sciences Prague, Czech Republic) and Mr. Jakub Mikulka (Department of Agroecology and Crop Production, Faculty of Agrobiology, Food and Natural Resources, Czech University of Life Sciences Prague, Czech Republic) for consultations and technical assistance.

\section{Author contributions}

M.K.S., K.H. and A.R. planned the experiments. P.K. had collected the samples. M.K.S. conducted the experiments. M.K.S., K.H. and A.R. performed the bioinformatics and statistical analysis. M.K.S., K.H., A.R. and J.S. analysed the results. M.K.S. and A.R. wrote the initial draft of the manuscript. M.K.S., K.H., A.R., P.K. and J.S. prepared the final manuscript. All authors have read and approved the final manuscript.

\section{Fundings}

This work was financially supported by the National Agency for Agricultural Research project (QK1820081). In addition, infrastructural support for molecular biology work is obtained from grant EVA 4.0", No. CZ.02.1.01/0.0 /0.0/16_019/0000803 financed by OP RDE, and the salary for A.R. is from 'EXTEMIT - K', No. CZ.02.1.01/0.0/ 0.0/15_003/0000433 financed by OP RDE.

\section{Competing interests}

The authors declare no competing interests.

\section{Additional information}

Supplementary Information The online version contains supplementary material available at https://doi.org/ 10.1038/s41598-021-92780-1.

Correspondence and requests for materials should be addressed to J.S.

Reprints and permissions information is available at www.nature.com/reprints.

Publisher's note Springer Nature remains neutral with regard to jurisdictional claims in published maps and institutional affiliations. 
(c) (i) Open Access This article is licensed under a Creative Commons Attribution 4.0 International cc) License, which permits use, sharing, adaptation, distribution and reproduction in any medium or format, as long as you give appropriate credit to the original author(s) and the source, provide a link to the Creative Commons licence, and indicate if changes were made. The images or other third party material in this article are included in the article's Creative Commons licence, unless indicated otherwise in a credit line to the material. If material is not included in the article's Creative Commons licence and your intended use is not permitted by statutory regulation or exceeds the permitted use, you will need to obtain permission directly from the copyright holder. To view a copy of this licence, visit http://creativecommons.org/licenses/by/4.0/.

(C) The Author(s) 2021 